\title{
Assessment of the symptoms of bruxism in young people in the last high-school grades
}

\author{
ZOFIA MACIEJEWSKA-SZANIEC ${ }^{1, A-G}$, BARBARA MACIEJEWSKA ${ }^{2, \text { A-E, }}$ \\ KATARZYNA MEHR ${ }^{1, D, G}$, PAWE \\ ' Clinic of Oral Rehabilitation, Poznan University of Medical Sciences \\ ${ }^{2}$ Chair and Clinic of Phoniatrics and Audiology, Poznan University of Medical Sciences
}

A - Study Design, B - Data Collection, C - Statistical Analysis, D - Data Interpretation, E - Manuscript Preparation, F - Literature Search, $\mathbf{G}$ - Funds Collection

Summary Background. Parafunctions are involuntary habits harmful to the chewing system. Tooth contact parafunctions are developed mostly under high emotional tension associated with stress. One of them is bruxism, i.e. teeth clenching and/or grinding. Young people in the last high-school grades are a group particularly predisposed to developing parafunctions due to high mental tension and long-lasting stress associated with the matura examination.

Objectives. Assessment of the symptoms of bruxism in young people in the last high-school grades 30 days before the matura examination.

Material and methods. 109 students (58 girls, 51 boys; aged $18.07 \pm 0.26$ years) examined 30 days before the matura examination. Every subject had a medical interview in the form of a survey containing questions about parafunctions and symptoms of dysfunction of the stomatognathic system, a medical interview, and a dental examination, including the symptoms of bruxism (vertical cracks within the enamel of the incisors and canines, teeth impressions on the side of the tongue body, palpation tenderness of the muscles of the chewing system).

Results. The incidence of bruxism symptoms in the investigated group was $76.1 \%$ (83 students). Only 38.5\% (42) students were aware of the problem of bruxism and reported it in at least one survey response. Higher incidence of the parafunction was observed in girls (teeth clenching under stress $p=0.0001$; morning pain of the facial muscles $p=0.0393$ ). The most common symptoms of bruxism were: increased tenderness of the muscles of mastication (71.5\%) and teeth abrasion (50.5\%).

Conclusions. 1. The symptoms of bruxism are present in most of the investigated young people, along with a poor awareness of the presence of this parafunction 2. The most common symptom of bruxism was palpation tenderness of the muscles of mastication.

Key words: stress, bruxism, parafunctions.

Fam Med Prim Care Rev 2016; 18(3): 282-285

\section{Background}

Parafunctions are incorrect, persistent, involuntary habits that, if repeated and uncontrolled, can have a deteriorating effect on the chewing system and its components (musculoskeletal system, temporomandibular joint and teeth with periodontium) [1]. These non-typical functions of the chewing system are qualitatively and quantitatively different from the physiological model [2]. There are two types of habits harmful for the chewing system: a) tooth contact parafunctions involving contact between teeth (bruxism - excessive and uncontrolled contact between teeth in the centric position, so-called teeth clenching, or in the eccentric position, teeth grinding); and b) non-tooth contact parafunctions without contact between the opposing teeth (compulsive gum chewing, biting of nails and skins around nails, chewing on foreign bodies such as pen caps, tongue parafunctions, biting the mucous membrane of the cheek or lips, occupational habits: biting threads or holding pins with teeth by tailors) [3-5]. In the literature, bruxism has been regarded as a 21 st century disease as it is becoming a common problem in society and occurs in patients representing every age group [6].

Bruxism has a complex and multifactorial etiology. Among the factors contributing to its occurrence are local factors, i.e. disorders related to tooth contact and articula- tion, such as obstacles to mandibular closure (premature contact between teeth, e.g. caused by excessive height of fillings) or malocclusions [3, 6, 7]. However, the key role in the development of this tooth contact parafunction is played by the increased emotional tension associated with civilizational stress [3, 8, 9]. Long-lasting stress and upsetting situations are suppressed in the subconscious, but the impossibility to relieve stress causes increased tonus in the muscle groups within the chewing system, mostly during sleep (so-called nocturnal bruxism) or less frequently during the day (so-called diurnal bruxism), when the control of consciousness is abolished $[2,8]$. This results in a very long and non-physiological load of tissues and, consequently, their damage. In many cases, the development of tooth contact parafunctions is related with the type of personality of the patient and the patient's ability to cope with stress [8,9].

Young people in the last high-school grades are a group particularly predisposed to developing bruxism due to high mental tension and chronic stress associated with preparations for the matura examination, the examination itself, as well as making the first important decisions regarding their future lives. Among the symptoms suggesting the presence of this harmful habit are: clearly visible abrasion of the enamel on the incisal edges of the teeth, abrasion fields on the tooth cusps, vertical cracks within the enamel, cicatricial thickening or hemorrhagic ecchymoses of the cheek mucosa next 
to the chewing surfaces of the lateral teeth, teeth impressions on the side of the tongue body, increased tonus of the muscles of the head, neck and shoulder girdle, as well as hypertrophy of the group of muscles involved in mastication $[3,6]$. Systemic symptoms (abdominal discomfort, tension headache, otological symptoms) [4, 10, 11] are also often reported by patients with bruxism. These symptoms, due to the uncommon extraoral location, can very often be difficult to diagnose.

\section{Objectives}

The aim of the study was to assess the type and frequency of the various symptoms of bruxism in young people in the last high-school grades.

\section{Material and methods}

The study group consisted of young people attending the last grades of the Dąbrówka High School no. 7 in Poznan, Poland. The study was conducted 30 days before the matura examination. A total of 109 students (58 girls, 51 boys) aged $18.07 \pm 0.26$ years (101 eighteen-year-olds, 9 nineteen-year-olds) were evaluated. Every subject had a medical interview in the form of a survey (the questions regarded the awareness of teeth clenching/grinding during the day (circumstances of occurrence) and/or night and under stress, morning tenderness of the facial muscles, presence of incorrect habits such as chewing gum, biting pencils or nails), specialist dental examination (extra- and intraoral), with a particular focus on the symptoms of bruxism using a special questionnaire prepared by dentists. The following elements were evaluated in the study: vertical cracks within the enamel of the incisors and canines, teeth impressions on the side of the tongue body, palpation tenderness of the muscles of the chewing system (masseter muscles, temporal muscles, medial pterygoids, lateral pterygoids, sternocleidomastoid muscles, suboccipital muscles). Moreover, the degree of dental abrasion was assessed using Martin's scale $\left(0^{\circ}-\right.$ no signs of abrasion; $I^{\circ}-$ uperficial abrasion of the enamel with cusps preserved, $\|^{\circ}$ - partial exposure of dentin; $I \mathrm{II}^{\circ}$ - formation of large contact areas without cusps, lack of enamel; IV ${ }^{\circ}$ - abrasion of the teeth at the necks; $\mathrm{V}^{\circ}$ - exposure of pulp chamber). The results were subjected to statistical analysis using the Statistica PL 10.0 (StatSoft) package. In order to determine the significance of the differences between the investigated groups, non-parametric tests were used (for qualitative variables: the chi-squared test or Fisher's exact test). The results were considered as statistically significant at $p<0.05$.

\section{Results}

The students exhibited high diversity and variability of the subjective and objective symptoms of bruxism. Of the 109 students, $38.5 \%$ (42) were aware of the problem of bruxism and reported it in at least one survey response. An analysis of selected survey questions is presented in Table 1. The students reported that teeth clenching/grinding was observed particularly frequently in stressful situations (a school test, solving a problem on a blackboard). The remaining $61.5 \%$ of the investigated group (67 students) were not aware of the presence of the parafunction in everyday life, but the specialist dental clinical examination revealed the presence of this harmful habit. The incidence of the symptoms of bruxism among the investigated young people was $76.1 \%$ (83 students). There was a statistically significant difference between the incidence of all symptoms of the parafunction in girls compared to that in boys (Tab. 1).
Table 1. Analysis of selected answers to the survey questions about parafunctions according to the sex of the investigated students

\begin{tabular}{|l|l|l|l|l|}
\hline $\begin{array}{l}\text { Selected survey } \\
\text { questions }\end{array}$ & Total & $\begin{array}{l}\text { Girls } \\
\boldsymbol{n}=\mathbf{5 8}\end{array}$ & $\begin{array}{l}\text { Boys } \\
\boldsymbol{n}=\mathbf{5 1}\end{array}$ & $\boldsymbol{p}$ \\
\hline $\begin{array}{l}\text { Teeth clenching/ } \\
\text { /grinding during } \\
\text { the day }\end{array}$ & 23 & 13 & 10 & 0.8158 \\
\hline $\begin{array}{l}\text { Teeth clenching/ } \\
\text { /grinding at night }\end{array}$ & 29 & 16 & 13 & 0.8314 \\
\hline $\begin{array}{l}\text { Teeth clenching } \\
\text { under stress }\end{array}$ & 40 & 31 & 9 & $\mathbf{0 . 0 0 0 1}$ \\
\hline $\begin{array}{l}\text { Morning tender- } \\
\text { ness of the facial } \\
\text { muscles }\end{array}$ & 35 & 23 & 12 & $\mathbf{0 . 0 3 9 3}$ \\
\hline
\end{tabular}

The statistically significant results are in bold.

The most common symptoms reported in the study were discomfort and pain of the lateral pterygoids and temporal muscles. In 69 students, bilateral hypertrophy of the masseter muscles was observed, and $100 \%$ of this group reported an additional parafunction, compulsive gum chewing, in the survey. Frequent bruxism symptoms also included pathological abrasion of the teeth, which occurred in 50.5\% (55) of subjects; $\mathrm{I}^{\circ}$ abrasion prevailed, while $\mathrm{II}^{\circ}$ abrasion was observed in $7.3 \%$ (8) of subjects. Clearly visible teeth impressions on the side of the tongue body were observed in $41.3 \%$ (45) and vertical cracks in the enamel were visible in $37.6 \%$ (41) of students. The results are reported in Table 2.

\begin{tabular}{|c|c|c|c|c|}
\hline $\begin{array}{l}\text { Bruxism } \\
\text { symptoms }\end{array}$ & $\begin{array}{l}\text { Palpation } \\
\text { tender- } \\
\text { ness of the } \\
\text { muscles of } \\
\text { mastication }\end{array}$ & $\begin{array}{l}\text { Pathologi- } \\
\text { cal abra- } \\
\text { sion of the } \\
\text { teeth }\end{array}$ & $\begin{array}{l}\text { Impres- } \\
\text { sions } \\
\text { on the } \\
\text { tongue }\end{array}$ & \begin{tabular}{|l|} 
Vertical \\
cracks \\
in the \\
enamel
\end{tabular} \\
\hline Girls & 46 & 35 & 30 & 27 \\
\hline Boys & 32 & 20 & 15 & 14 \\
\hline$p$ & 0.0879 & \begin{tabular}{|l|l|}
0.0352 \\
\end{tabular} & 0.0206 & 0.0487 \\
\hline
\end{tabular}

The statistically significant results are in bold.

\section{Discussion}

Bruxism is the most widespread tooth contact parafunction in the population. In the literature, the incidence of bruxism is reported at various levels between $50 \%$ and $80 \%$ [2]. Although this harmful parafunction occurs in every age group, the highest percentage of uncontrolled teeth clenching or grinding is reported in people under 30 years of age $(54.67 \%)[11,12]$. Numerous population studies show the worrying phenomenon of the gradual reduction of the age of patients with bruxism. In the investigated group, the incidence of bruxism was as high as $76.1 \%$, while Mankiewicz et al. reported even higher incidence - among 303 students, only 16 were free of the signs and symptoms of this parafunction [8]. Among the causes of the increasing number of patients with bruxism, particular attention should be given to the increasing level of stress, which generates increased mental tension, and the concurrent lack of appropriate skills to handle the considerable mental load [11, 13, 14]. For high-school graduates, the time to make the first important decisions regarding their future lives (choosing studies, first job) is psychologically a very difficult period in life. Long-lasting stress, high expectations from relatives 
and teachers, significant mental effort, and the concurrent period of youthful rebellion make 18- and 19-year-olds a group strongly predisposed to developing a tooth contact parafunction, such as bruxism. Based on numerous psychological tests and clinical studies, it was found that certain personality traits (high level of neuroticism, perfectionism, mindset for achieving success, the need to control, hyperactivity) predispose subjects to a quicker development of this harmful habit $[9,13,14]$. Baron et al. conducted studies assessing the impact of increased emotional tension on the incidence of bruxism using a self-awareness worksheet [15]. It was observed that bruxism occurred more frequently in people with increased mental tension [15]. On the other hand, Mankiewicz al. found no clear link between bruxism and personality traits $[8,13]$.

Most authors agree that bruxism is diagnosed more frequently in women due to their higher sensitivity [5-8]. This hypothesis was confirmed in the presented study - a statistically significant difference was found between the incidence of all investigated parafunctional symptoms in girls and boys.

Patients are very rarely aware of the signs and symptoms of bruxism. The pathological alterations of the structure of the chewing system associated with this parafunction can initially develop asymptomatically, and bruxism is usually diagnosed late, based on the irreversible consequences of morphological and functional nature, located in the hard tissues of the teeth, periodontium and temporomandibular joints $[4,6]$. Therefore, detailed dental examination is helpful in the verification of the results of the survey regarding the symptoms of bruxism, which in this study showed that among 109 surveyed students, only 38.5\% (42) were aware of the problem of their parafunction. More than half, i.e. $61.5 \%$ (67), did not notice this parafunction in everyday life. This may suggest that knowledge about bruxism is scarce among patients despite multiple education and prevention programmes. Very often, bruxism is not the only harmful habit. Studies by Panek and Mankiewicz demonstrated that the occurrence of single parafunctions is very low (approximately $1 \%$ ). However, double parafunctions (bruxism associated with compulsive gum chewing or nail biting) was observed in $40 \%$ of subjects $[7,8]$. In as many as $86 \%$ of cases, the consequences of bruxism were pain sensations of the face, masseter muscles, neck, arms, and head [3, $4,6,10]$. As a result, approximately $55 \%$ of patients with bruxism may experience discomfort in everyday functioning, which affects the quality of life [6]. The chewing system is a functional-morphological system subject to dynamic changes throughout life. It has a certain capacity to adapt to changes occurring within its components, but once this adaptive capacity is exceeded, irreversible changes develop and are often accompanied by pain [10]. The investigated group consisted of young people in whom the processes of adaptation to changes within the chewing system should be well developed. It is therefore worrying that $71.5 \%$ (78) of subjects experienced tenderness of any investigated muscle at such a young age. The subjects reported pain upon intraoral palpation of the lateral pterygoids, which is typical of people with dysfunctions of the chewing system [8]. Headache (mostly in the temporal region), often reported by patients with excessive teeth clenching/grinding $[2,4]$, can be caused by excessive tonus of the temporal muscles, which was observed in the study.

Bruxism is considered to be the most damaging tooth contact parafunction for the chewing system. The loss of enamel resulting from teeth grinding within six months is four times greater in people with bruxism than in people without bruxism [16]. In the presented study, abrasion of the teeth occurred in a total of 50.5\% (55) of subjects. Prevailing was $\|^{\circ}$ abrasion or partial exposure of dentin, particularly visible in the incisors and canines. However, eight girls already exhibited $\mathrm{II}^{\circ}$ abrasion, which constitutes a concern and suggests a strong emotional background. Teeth impressions on the tongue, another common symptom of bruxism reported in the literature [4-7], were observed in 41.3\% (45) of subjects. Moreover, along with the symptoms of bruxism, the subjects reported otological symptoms such as tinnitus, which have been confirmed by numerous scientific reports $[10,11,17]$. These problems significantly affect the everyday life of the patients and impair their functioning, decreasing the quality of life and productivity. Therefore, a comprehensive approach to the treatment of patients with bruxism is recommended.

The presented study does not exhaust the topic. Based on the obtained results, it would be reasonable to conduct studies assessing the impact of educational and psychological assistance programmes on the reduction of the symptoms of bruxism. Therefore, a multidimensional and multidisciplinary approach focused on all-around patient observation should be the goal pursued by dentists and family physicians.

\section{Conclusions}

1. Most of the investigated young people exhibited the symptoms of bruxism, along with a poor awareness of the presence of this parafunction, which indicates the need to implement educational programmes in schools to explain the harmful effects of bruxism on the stomatognathic system.

2. Palpation tenderness of the muscles of the chewing system was the most common symptom of bruxism in the clinical examination.

3. In periods of stress (matura exam), an increase in the intensity of the symptoms of bruxism occurs, particularly in girls.

Source of funding: This work was funded by the authors' resources. Conflict of interest: The authors declare no conflict of interests.

\section{References}

1. Majewski S, Wieczorek A, Loster J, et al. Mięśnie żucia i stawy skroniowo-żuchwowe w aspekcie fizjologicznych funkcji układu stomatognatycznego. Protet Stomatol 2010; LX(1): 10-16.

2. Śmierciak A. Bruksizm - definicja, diagnostyka i leczenie. Porad Stomatol 2007; 6(1): 34-41.

3. Siemińska-Piekarczyk B, Zadurska M, Biedrzycka E, et al. Etiologia i objawy kliniczne bruksizmu u dzieci i młodzieży na podstawie piśmiennictwa i własnych obserwacji. Czas Stomatol 1998; 51(1): 47-51.

4. Prośba-Mackiewicz M, Wytrykowska A, Mackiewicz J. Subiektywne i obiektywne objawy zaburzeń czynnościowych w układzie stomatognatycznym. Dent Forum 2008; 36L(1): 17-21.

5. Rasławska J, Dawid K, Janiszewska-Olszowska J. Występowanie bruksizmu u przyszłych stomatologów. Mag Stomatol 2008; 18(7-8): 72-76.

6. Ziółkowska-Kochan M, Kochan J, Pracka D, et al. Bruksizm - problem interdyscyplinarny. Czas Stomatol 2007; 60(6): 391-397. 
7. Panek H, Nowakowska D, Maślanka T, et al. Epidemiology of temporomandibular dysfunctions in young adult populations studied in Department of Prosthodontics, Silesian Piast University of Medicine in Wrocław, Poland. Dent Med Probl 2007; 44(1): 55-59.

8. Mankiewicz M, Panek H. Występowanie parafunkcji narządu żucia u młodocianych. Dent Med Probl 2005; 42(1): 95-101.

9. Frączak B, Ey-Chmielewska H, Zarek A. Wpływ czynników psychosocjologicznych i psychoemocjonalnych na możliwość generowania dysfunkcji stawu skroniowo-żuchwowego w badaniach ankietowych studentów stomatologii. Dent Forum 2008; 36(2): 27-31.

10. Maciejewska-Szaniec Z, Maciejewska B, Piotrowski P, et al. Charakterystyka zaburzeń czynnościowych układu stomatognatycznego u pacjentów audiologicznych. Fam Med Prim Care Rev 2014; 16(3): 255-256.

11. Mehr K, Piotrowski P, Maciejewska Z, et al. The manifestation of selected otological symptoms and stomatognathic system dysfunction in youth of secondary school. Wellness in different phases of life. Lublin: Wydawnictwo NeuroCentrum; 2011: 83-93.

12. Rasławska J, Dawid K, Janiszewska-Olszowska J. Występowanie bruksizmu u przyszłych stomatologów. Mag Stomatol 2008; 8(7): $72-76$.

13. Mankiewicz M, Panek H. Zależność nasilenia dysfunkcji stawów skroniowo-żuchwowych od poziomu neurotyzmu i ekstrawersji według Eysencka. Dent Med Probl 2005; 42(4): 605-609.

14. Panek H, Śpikowska-Szostak J. Wpływ stresu i cech osobowości na dysfunkcje skroniowo-żuchwowe i bruksizm na podstawie piśmiennictwa i badań własnych. Dent Med Probl 2009; 46(1): 11-16.

15. Baron S, Herman J, Wojtyna J. Aspekt zaburzeń emocjonalnych u młodzieży szkół średnich w rozwoju parafunkcji i dysfunkcji stawów skroniowo-żuchwowych. Mag Stomatol 2003; 13(10): 68-71.

16. Sierpińska T, Gołębiewska M. Wpływ zaburzeń morfologiczno-czynnościowych układu stomatognatycznego na jakość starcia zębów. Protet Stomatol 2006; LVI(5): 342-345.

17. Tuz HH, Onder EM, Kisnisci R. Temporomandibular disorder (TMD) is associated with an increased prevalence of otologic complaints. J Evid Based Dent Pract 2004; 4(2): 167-168.

Address for correspondence:

Zofia Maciejewska-Szaniec MD, PhD

Klinika Rehabilitacji Narządu Żucia UM

ul. Bukowska 70

60-812 Poznań

Polska

Tel.: +48 507 599-414

E-mail: zofiamaciejewska@wp.pl

Received: 17.03.2016

Revised: 13.04.2016

Accepted: 22.04.2016 